$\begin{array}{ll} & \text { Etnográfica } \\ \text { etnográfica } & \text { Revista do Centro em Rede de Investigação em }\end{array}$

Antropologia

vol. 11 (1) | 2007

Vol. $11(1)$

\title{
"A caminhada até às aldeias": a ruralidade na transição para a democracia em Portugal
}

"The journey to the villages": rurality in the transition to democracy in Portugal

\section{Sónia Vespeira de Almeida}

\section{(2) OpenEdition}

\section{Journals}

\section{Edição electrónica}

URL: https://journals.openedition.org/etnografica/1875

DOI: 10.4000/etnografica. 1875

ISSN: 2182-2891

\section{Editora}

Centro em Rede de Investigação em Antropologia

\section{Edição impressa}

Data de publição: 1 maio 2007

Paginação: 115-139

ISBN: 0873-6561; E-ISBN 2182-2891

ISSN: 0873-6561

\section{Refêrencia eletrónica}

Sónia Vespeira de Almeida, "A caminhada até às aldeias": a ruralidade na transição para a democracia em Portugal», Etnográfica [Online], vol. 11 (1) | 2007, posto online no dia 25 setembro 2012, consultado o 11 fevereiro 2022. URL: http://journals.openedition.org/etnografica/1875 ; DOI: https://doi.org/10.4000/etnografica.1875

\section{(c) (1) (8)}

Etnográfica is licensed under a Creative Commons Attribution-NonCommercial 4.0 International License. 


\title{
"A caminhada até às aldeias": A ruralidade na transição para a democracia em Portugal
}

\section{Sónia Vespeira de Almeida}

\begin{abstract}
O presente artigo procura examinar a equação "povo-ruralidade" no quadro da transição democrática portuguesa, tomando como corpo empírico as Campanhas de Dinamização Cultural e Acção Cívica do Movimento das Forças Armadas (1974-1975). Procurando contrariar a versão folclórica do país promovida pelo Estado Novo, os protagonistas desta iniciativa constroem um campo discursivo paradoxal, onde se entretecem conceitos como cultura, tradição, subdesenvolvimento, descentralização e cidadania.

PALAVRAS-CHAVE: camponeses, cultura popular, revolução, Movimento das Forças Armadas.
\end{abstract}

1 .

Entre os finais de 1974 e o Verão de 1975 João Abel Manta desenhou um conjunto de cartazes para ilustrar as Campanhas de Dinamização Cultural e Acção Cívica do Movimento das Forças Armadas (MFA). Em MFA, Sentinela do Povo (Maio de 1975), uma família de camponeses surge isolada no canto inferior esquerdo da composição, recolhida sobre si própria, encontrando-se no outro extremo da diagonal, um militar de atalaia, sentado sobre a grande sigla do MFA. Esta assume a centralidade do espaço pictórico, tal como em O Povo Está com o MFA (Julho de 1975). Neste cartaz a mensagem reorganiza-se. O militar desce ao plano das figuras que, sobrepostas na sigla MFA, a este se dirigem estendendo-lhe os braços, oferecendo alimentos e outros objectos, numa invocação directa da ruralidade, feita também pela introdução de elementos que remetem para a economia camponesa.

Como afirmou José Cardoso Pires (1975), os cartoons de João Abel Manta são subtis na forma com medem a "temperatura social" dos contextos sociopolíticos que convoca para os seus desenhos. O pintor apresenta-nos, assim, a 
uma das figuras que, conjuntamente com o herói colectivo (Cruzeiro 1994) - o MFA -, se esperaria que se transformasse num dos actores centrais da revolução: o camponês. Por outro lado, Abel Manta revela, também, a ambiguidade que este adquiriu no processo de transição democrática. O camponês para cumprir esta missão precisava de ser esclarecido, para que o país falasse todo "a mesma língua", pondo em "contacto tudo aquilo que está em planos diferentes" (Correia et al. s/d: 76). As Campanhas de Dinamização Cultural e Acção Cívica do MFA permitiriam, assim, a passagem do país estático retratado na primeira imagem à nação desejada ou à nação "em movimento" (Pires 1999: 225) representada na segunda.

Estas duas paisagens da revolução servem de mote para introduzir a problemática do presente artigo, que procurará examinar a equação "povo-ruralidade" no quadro da transição democrática portuguesa, tomando como corpo empírico as Campanhas de Dinamização Cultural e Acção Cívica do Movimento das Forças Armadas (1974-1975).

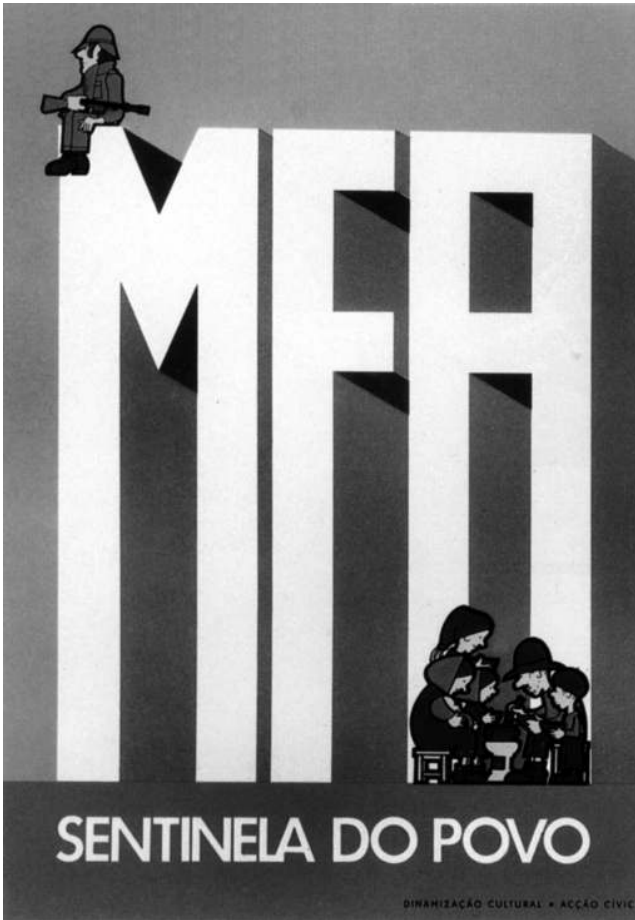

Figura 1

MFA, Sentinela do Povo.

João Abel Manta/CODICE, 1975.

(Arquivo particular de Rodrigo de Freitas)

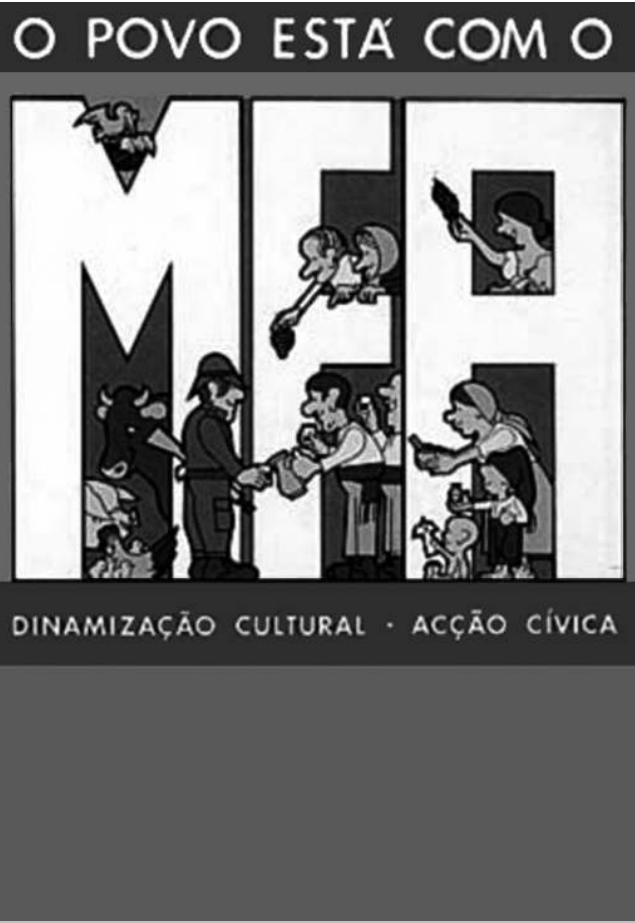

Figura 2

O Povo Está com o MFA.

João Abel Manta/CODICE, 1975.

(Arquivo particular de Rodrigo de Freitas) 
Por intermédio da análise desta iniciativa proponho uma interpelação das construções discursivas sobre a sociedade rural portuguesa como "teorias nativas" (Neiburg 1997), isto é, procuro interrogar estes discursos como interpretações de uma realidade social específica, num contexto histórico e político determinado. Os protagonistas das Campanhas de Dinamização serão, assim, concebidos como intérpretes de um país ao qual se procurava dar visibilidade.

Procurando contrariar a "retórica da invisibilidade", para utilizar a expressão de José Gil (1995) ao caracterizar os discursos de Salazar, neste período a retórica é a da visibilidade, marcada, como afirmou Eduardo Lourenço, pela "tentativa frenética de deslocar a imagem fascista da realidade nacional presente e passada, de destruir pela raiz o que se supunha mera pintura superficial ${ }^{1}$ do País" (1988: 44). O "Portugal revolucionário" é, então, apresentado como um momento de rupturas. Contudo, tal como referiu Marx no 18 Brumário de Louis Bonaparte:

Os homens fazem a sua história mas não arbitrariamente, nas condições escolhidas por eles, mas antes sob as condições directamente herdadas e transmitidas pelo passado. E mesmo quando parecem ocupados em transformar-se, a eles e às coisas, em criar algo absolutamente novo, é precisamente nessas épocas de crise revolucionária que se evocam os espíritos do passado [...]. (Marx 1975 [1869]: 13).

De facto, nos processos de transição do autoritarismo para a democracia, os novos regimes ajustam contas com os seus passados pré-democráticos (Elster 1998) e, neste sentido, as Campanhas de Dinamização Cultural e Acção Cívica do MFA assumiram um importante papel na denúncia do legado fascista, sendo em grande parte a partir do legado do regime deposto que se "imaginou" a nação (Anderson 1991). Durante este período imperou de facto a retórica da visibilidade que se alimentou, que se nutriu de um tempo pretérito, isto é, dialogou com os conteúdos de um passado ditatorial, denunciando-o e tornando-o público. Esta foi uma das vias que conferiu legitimidade ao discurso do MFA, permitindo às Campanhas de Dinamização Cultural e Acção Cívica aceder a uma imagem de Portugal que se procurava pôr em circulação nesta conjuntura histórica. Neste desvelar do país, num contexto de aceleração histórica (Hann 1994), a equação "povo-ruralidade" caracteriza, de forma insistente, as construções discursivas sobre Portugal, onde os camponeses e a ruralidade "a norte" surgem como destinatários privilegiados da acção do MFA. 
2.

O 25 de Abril de 1974 e a mobilização popular que se lhe seguiu configuraram um momento anómalo na história dos movimentos sociais em Portugal (Palácios 2003: 20), que "os discursos sempre tinham garantido não fazer parte da natureza do povo português" (Trindade 2004: 31). Esta mudança política inaugurou um novo ciclo de desocultamento e de descoberta do país palmilhado por uma plêiade de experiências ocorridas entre os anos de 1974 e 1976. A par de iniciativas promovidas pelo sector militar, onde se situam as Campanhas de Dinamização Cultural e Acção Cívica do MFA, a sociedade civil assumiu, também, um importante papel nas tarefas da revolução, mobilizando-se em acções das quais se destacam as Campanhas de Alfabetização e Educação Sanitária dirigidas pela Pró-União Nacional dos Estudantes Portugueses, o Serviço Ambulatório de Apoio Local, o Serviço Cívico Estudantil, o Serviço Médico na Periferia. Como notou Raposo, “o 'povo’ redefine-se, os intelectuais e artistas 'descem' à rua e 'partem' à redescoberta da aldeia” (1998: 196).

Passados seis meses do dia 25 de Abril de 1974 é apresentado o Programa de Dinamização Cultural e Esclarecimento Político, em conferência de imprensa no Palácio Foz em Lisboa. Em colaboração com a Direcção-Geral da Cultura Popular e Espectáculos é atribuída à Comissão Dinamizadora Central (CODICE), estrutura da 5. ${ }^{a}$ Divisão do Estado-Maior General das Forças Armadas, a missão de lançar e coordenar as Campanhas de Dinamização Cultural e Acção Cívica do MFA, com a finalidade de "preencher o vácuo cultural e de informação política existente em todo o País" (Correia et al. s/d: 21).

$\mathrm{O}$ discurso legitimador desta iniciativa caracteriza-se pela recorrência do tema da "reconstrução nacional" e pelas constantes alusões ao passado repressivo (Pinto 2004). A linguagem utilizada identifica o fascismo como o inimigo que urge erradicar no âmbito do processo de reconstrução do país, sinónimo de "desfascização" e de participação cívica. As linhas mestras do Programa de Dinamização Cultural e Esclarecimento Político contemplavam assim:

a) Luta anti-fascista;

b) Esclarecimento do Programa do MFA;

c) Apoio às FA;

d) Isenção partidária;

e) Análise e discussão da problemática nacional;

f) Inteligência política de actuação, considerando que cada comunidade possui uma cultura própria que não deve ser agredida. Pretende-se levar informação e estabelecer um diálogo que permita a participação no processo de democratização em que o País se encontra envolvido a partir dos problemas efectivamente vividos por essa comunidade. (Correia et al. s/d: 22). 
A Dinamização Cultural tem início em Outubro de 1974. Até ao 11 de Março de 1975, as campanhas obedecem a um modelo itinerante, possibilitando o levantamento das principais carências das populações, tendo-se privilegiado como modo de actuação a sessão de esclarecimento, com a representação de uma peça de teatro ou a projecção de um filme. Segundo o Livro Branco da 5. Divisão 1974-1975 (1984) foram realizadas cerca de 10 mil sessões de esclarecimento. ${ }^{2}$ Contudo, as campanhas, enquanto modelo organizativo, que implicava a fixação no terreno de meios técnicos e culturais, sobretudo nas sedes de concelho, incidiram no Norte e Centro de Portugal, nomeadamente nas zonas rurais do Minho ("Operação Verdade" e "Operação Alvorada"), Trás-os-Montes ("Nortada" e "Maio-Nordeste"), Beira Alta (distritos de Viseu e da Guarda), Beira Baixa (distrito de Castelo Branco) e ainda no arquipélago dos Açores ("Operação Atlântida").

Relativamente à zona Sul do país realizou-se uma curta acção no Algarve ("Operação Povo Culto") e esteve prevista a realização de uma campanha no Alentejo que viria a ser cancelada devido à extinção da CODICE, a 26 de Novembro de 1975. Importa sublinhar que a preferência pelo interior Norte e Centro do país foi justificada pelos protagonistas das Campanhas de Dinamização Cultural "pelo subdesenvolvimento cultural e político" destas áreas e pela influência dos caciques laicos ou eclesiásticos, estruturas emblemáticas do poder local no Estado Novo. Estes foram os terrenos eleitos de actuação, a partir dos quais foram elaboradas imagens sobre o mundo rural, em concreto sobre as zonas de agricultura familiar.

Os acontecimentos do 11 de Março de 1975 precipitam a reestruturação das Campanhas de Dinamização Cultural, às quais é acrescentada uma nova dimensão: a Acção Cívica. Esta nova etapa é fundamentada pelas experiências das acções anteriores apostando-se, agora, em campanhas de longa permanência. Para justificar esta mudança de actuação, Ramiro Correia alicerça o seu discurso no desvelar de um país até então desconhecido:

Como sabem nós começámos em Outubro as nossas Campanhas de Dinamização Cultural e esclarecimento cívico da população. Achámos que era fundamental essa acção junto da população por motivos vários: por um lado porque nós, efectivamente, não conhecíamos bem o País que tínhamos, não nos deixavam conhecer o País e, portanto, não se pode fazer uma revolução em país nenhum quando não se conhece a realidade desse país $[\ldots] .^{3}$

2 Esta cifra contabiliza as sessões realizadas em território nacional e nas comunidades de emigrantes portugueses na Europa (em articulação com a Secretaria de Estado da Emigração) até à extinção da CODICE em Novembro de 1975.

3 Diário Popular, 17/3/1975, p. 20. 
Note-se que os objectivos da Dinamização Cultural foram sendo reestruturados de acordo com a experiência acumulada das campanhas anteriores e com os problemas específicos de cada "terreno". Ao privilegiarem o contacto directo com as populações rurais, permitiram, também, ao MFA advogar-se como "locutor legítimo" (Bourdieu, 1998 [1982]) do povo português e apresentar-se como depositário daquilo que James Scott (1998) designou de metis, ao problematizar as razões do fracasso de alguns projectos de engenharia social. Metis para Scott seria, assim, o conhecimento local, um conhecimento prático, o know-how (1998: 6) cuja exclusão inviabilizou, na sua óptica, projectos desenvolvidos por Estados autoritários para melhorar os quotidianos das populações e que falharam por desconhecimento das realidades que pretendiam transformar. De facto, num contexto político antagónico, este tipo de conhecimento é invocado para justificar as mutações que as Campanhas de Dinamização Cultural e Acção Cívica do MFA vão sofrendo durante o processo de transição para a democracia caracterizado pela indefinição, por hesitações relativas ao sentido da mudança social, pela confusão ideológica, pela sobreposição de estratégias, pela tensão entre os vários protagonistas, nomeadamente no seio do MFA.

Para além da componente militar, cujo trabalho incidiu na elucidação do Programa do MFA, no esclarecimento sobre as eleições para a Assembleia Constituinte, que se viriam a realizar no dia 25 de Abril de 1975, no melhoramento de infra-estruturas e no esclarecimento médico-sanitário, a Dinamização Cultural contou com um conjunto diversificado de contribuições oriundas de diversas áreas culturais: artes plásticas e gráficas, teatro, cinema, música, dança e circo.

O dever simétrico de retribuir ao MFA uma dádiva encontra-se subjacente aos discursos do sector intelectual da CODICE, que coloca a sua participação nas Campanhas de Dinamização Cultural e Acção Cívica do MFA no quadro de uma relação de troca como se, e no trilho de Marcel Mauss (1988 [1950]), a recusa de um convite fosse sinónimo de recusar uma aliança. João Mota, que colaborou com o sector do teatro da CODICE, afirma neste sentido:

Quando fomos convidados para as Campanhas do MFA ficámos bastante contentes. Convém não esquecer que o MFA era nessa altura [...] a grande linha. Tinha sido através do MFA que tínhamos ganho a nossa independência, a liberdade, a saída do fascismo. [...] Tínhamos que ter esse agradecimento ao MFA. (Cassete n. ${ }^{\circ} 41,2004$ )

A referência à "descentralização cultural” é dominante nos discursos dos responsáveis da Dinamização Cultural e será este objectivo que fará convergir o sector intelectual para este projecto que, de forma voluntária, vai partilhar com os militares a responsabilidade na construção da nação, oferecendo às populações as suas produções culturais e procurando simultaneamente uma aprendizagem, através do contacto com as especificidades das culturas locais. 
Apesar de não constar do Programa de Dinamização Cultural e Esclarecimento Político, a intervenção nos sectores do desporto e da agricultura assumiu uma significativa relevância no quadro das campanhas, em articulação com a Direcção-Geral dos Desportos e com o Ministério da Agricultura respectivamente. ${ }^{4}$

3.

Com a revolução, o país, que "se embelezava ordeiramente para si próprio" (Brito 1995: 11), é surpreendido por um novo ciclo de buscas e apropriações. A imagem coreografada da nação dá lugar a uma contra-imagem reveladora de um país em transformação, marcado por fortes carências socioeconómicas, resultado das políticas de um Estado fascista, agora derrotado. O Portugal democrático é, assim, construído numa relação de oposição com o regime anterior, assumindo o conceito de "povo" um carácter estruturante e paradoxal no universo e estratégia simbólica desenvolvidos pelos agentes e protagonistas das Campanhas de Dinamização Cultural e Acção Cívica do MFA. Esta iniciativa acentua, assim, a dimensão inventada (Hobsbawm e Ranger 1989 [1983]) ou imaginada (Anderson 1991 [1983]) dos processos culturais. Como afirma Pérez Ledesma (1997):

Las tradiciones, las naciones, las clases y los pueblos, el género y los movimientos sociales, y hasta los héroes y los líderes políticos se nos presentan ahora como el resultado de procesos de construcción cultural; de 'invenciones', si se quiere utilizar un término de espectacular éxito en la bibliografia histórica de la última década. (1997: 10-11)

Nesta linha, o sentido que a ideia de "povo" adquire depende de uma problemática teórica precisa, reequacionada de modo a permitir a construção de um problema científico que, no presente caso, procura esclarecer o universo de sentidos e a forma como este conceito se reifica numa das propostas da agenda revolucionária. A sua eficácia reside na sua historicização (Thompson 1998; e Silva 1994), uma vez que constitui um conceito discriminatório, revestindo-se de um carácter ambíguo que, de acordo com as diferentes conjunturas históricas, inclui ou exclui determinada categoria da população ou classe social (Julliard 1992), não podendo, como afirmou Joaquim Pais de Brito, "ser pensado e existir sem o discurso que o designa" (1995: 22). Na esteira de Bourdieu (1996 [1984]), as diferentes representações do "povo” emergem de

4 No que concerne ao sector agrícola, a CODICE contou com a colaboração de agrónomos no esclarecimento de um conjunto de medidas legislativas que constituíam o projecto de Reforma Agrária nas zonas de agricultura familiar do Norte do país. Das medidas a implementar destacam-se: a extinção de foros, a devolução dos baldios às populações, a lei do arrendamento rural, o apoio às cooperativas agrícolas e extinção dos grémios da lavoura, intervenção ao nível da comercialização de produtos agrícolas e gados, implementação de seguro das culturas, introdução do sistema de segurança social. 
uma relação que depende da posição ocupada em cada campo pelos actores sociais envolvidos, reenviando para o papel axial que este conceito assume na legitimação das ideologias.

Michel Foucault descreve em As Palavras e as Coisas (1998) o quadro Las Meninas do pintor espanhol Velázquez aludindo, através da análise dos diferentes elementos e personagens da representação, à relação de cumplicidade que o pintor constrói com o espectador que perscruta a obra. Também os protagonistas da Dinamização Cultural foram hábeis na construção e divulgação ${ }^{5}$ de uma paisagem discursiva sobre Portugal, procurando uma relação de cumplicidade com os actores sociais envolvidos para que a sua "visão do mundo social" (Bourdieu 1998 [1982]) fosse eficaz. Entendidas como parte integrante de um projecto político, as Campanhas de Dinamização Cultural e Acção Cívica do MFA procuravam "produzir e impor representações [...] do mundo social, capazes de agir sobre esse mundo ao mesmo tempo que agem sobre a representação que dele fazem os seus agentes" (Bourdieu 1998 [1982]: 135). De facto, a aproximação ao popular não legitimou apenas a formação das nações modernas, concorreu também para validar outros projectos políticos centrados na libertação "dos oprimidos" e na resolução da "luta de classes" (Canclini 1997: 209).

Garantir a eficácia de uma visão do mundo subjacente a um projecto revolucionário tornou central o conceito de "povo" enquanto colectivo nacional e indiferenciado no período da transição democrática portuguesa. Tal como a formulação de Smith sobre o modelo étnico de nação, o "povo" surge nesta conjuntura como "tribunal retórico de última instância" (1997 [1991]: 26), em nome do qual se justifica uma acção política. Personifica o princípio espiritual da democracia, constituindo um conceito político englobante, é o "povo-nação" destinado a transcender todas as distinções sociais (Julliard 1992: 185) e, neste sentido, é um conceito "interclasses" (Smith 1997 [1991]: 26).

Entendido como "todos os portugueses", tal como é referido no Programa do Movimento das Forças Armadas, o "povo" é resgatado como principal aliado de um projecto político que procurava propor e legitimar uma revolução integradora, sendo o MFA o intérprete das "aspirações e interesses da esmagadora maioria do Povo Português", justificando a sua acção "em nome da salvação da Pátria". ${ }^{6}$ Todavia, o Programa revela os níveis de hierarquização desta categoria, fazendo-lhe corresponder "as camadas da população até agora mais desfavorecidas "introduzindo, ainda, um novo elemento - as "classes trabalhadoras" - cujos interesses pretendia defender com uma "nova política social". ${ }^{7}$

5 Importa sublinhar que as Campanhas de Dinamização Cultural e Acção Cívica do MFA foram na época objecto de uma cobertura mediática intensa.

6 Programa do Movimento das Forças Armadas, s/d, [1974]:1. Arquivo Histórico do Ministério da Defesa Nacional (em organização); caixa 6355.

7 Programa do Movimento das Forças Armadas, s/d, [1974]:3. Arquivo Histórico do Ministério da Defesa Nacional (em organização); caixa 6355. 
Esta estratégia discursiva, simultaneamente inclusiva e exclusiva, encontra-se presente no período de lançamento das campanhas, sendo paulatinamente abandonada, adquirindo a ideia de "povo" conteúdos específicos à medida que esta iniciativa se desenrola, lidos não só a partir dos lugares que percorreu, dos discursos dos seus protagonistas, como também dos documentos que foram legitimando as suas modificações ao longo do processo de transição. Num movimento análogo ao "do it yourself kit", na expressão de Orvar Löfgren (1989) ou ao "sistema IKEA", nas palavras de Thiesse (2000), esta iniciativa assentou num processo de selecção dos grupos sociais que enformam a "comunidade política" (Smith 1997 [1991]) portuguesa. Desta forma, a "ressemantização" do conceito de povo espelha um "recorte da realidade", validando uma mundividência, aglutinando identidades, "operando como sinais diacríticos, isto é, sinais que conferem uma marca de distinção" (Oliven 1992: 26).

"O que é a Política?" constitui o título de um dos Textos de Apoio publicados sob a chancela da CODICE para orientação das equipas de Dinamização Cultural no terreno, constituindo um documento modelar para trabalhar o espectro das diferentes acepções da palavra "povo" e das figuras sociais que lhe correspondem no quadro da iniciativa que aqui me ocupa. Ao longo do texto são apresentadas definições de democracia (democracia burguesa e democracia popular), socialismo (socialismo burguês e proletário) e comunismo. Outra das definições que importa fixar é a de "povo":

O que é o Povo? Será que todos os habitantes de Portugal pertencem ao Povo? Um operário, um camponês, um empregado de escritório, um empregado de comércio, etc., pertencem efectivamente ao Povo. Mas os capitalistas pertencem ao Povo? Claro que não, estes homens não são Povo, mas sim exploradores do Povo. A nosso ver também não pertencem ao Povo todas aquelas pessoas cujo trabalho consiste em oprimir e explorar os trabalhadores por conta de capitalistas [...].

Então o que é o Povo? Entendemos que só pertencem ao Povo aquelas pessoas que criam riquezas ou que para isso contribuem. Povo é portanto o conjunto dos trabalhadores de um país. ${ }^{8}$

Este documento é revelador não só da centralidade e da ambiguidade que a categoria de "povo" adquiriu no período em análise, como também denuncia a tentativa de hierarquização dos seus graus de pureza. Numa sessão realizada numa freguesia de Barcelos, um dia após o 11 de Março de 1975, um elemento do MFA, ao aplicar os conteúdos deste texto, assegura:

8 Comissão Dinamizadora Central, “O que é a Política?”, Texto de Apoio 9. Centro Documentação 25 de Abril. Fundo Comunicados e Panfletos, caixa Forças Armadas-EME, Pasta EME, Gabinete de Dinamização do Exército, Diversos. 
[...] o 25 de Abril deu oportunidade do povo, a partir de agora, tomar nas suas mãos o destino deste país. É por isso que nós temos que avançar na construção da sociedade democrática, mas uma democracia autêntica, não podemos deixar-nos enganar com palavras. Temos que saber bem o que queremos.

[...] os militares do MFA para além de terem arriscado todo o seu prestígio e até as suas próprias vidas no 25 de Abril, já o provaram no 28 de Setembro, provaram-no ontem que estão dispostos a lutar até à última, estão dispostos a que de batalha em batalha, de vitória em vitória, na guerra final seja uma vitória do povo trabalhador. E para nós povo trabalhador são os operários, são os pescadores, são os jornaleiros, são os rendeiros, são os pequenos e médios camponeses, são os pequenos e médios comerciantes, são os pequenos e médios industriais, os outros, os exploradores, esses não. ${ }^{9}$

O MFA defende, ainda, num artigo sobre a agricultura portuguesa, que as classes mais "exploradas durante a longa vigência do regime deposto" são "as classes trabalhadoras braçais - os operários e camponeses. ${ }^{10}$

Todas estas passagens apresentam um consenso em torno da representação de "povo" difundida pela esquerda militar e civil no quadro da transição democrática portuguesa, onde este surge como sinónimo de trabalho, assente na retórica marxista da luta de classes. Constitui uma figura definida por oposição, por aquilo que não representa e, neste caso, não representa as "classes exploradoras". Neste período o "povo" surge como um importante actor histórico, situando-se na intersecção de duas das figuras identificadas por Julliard (1992: 191-192) no quadro da Revolução Francesa: o "povo-tiers état" que elimina os privilegiados, sendo a fórmula na qual mais se reconhece a esquerda francesa, e o "povo dos trabalhadores" que constitui uma visão mais social e simultaneamente mais restrita da anterior.

Contudo, os discursos e as práticas subjacentes às Campanhas de Dinamização Cultural e Acção Cívica do MFA permitem avançar um pouco mais na problematização deste processo de selecção e manipulação de categorias, e concluir que são os camponeses $^{11}$ e a ruralidade a norte que são resgatados pelo MFA para representar o "povo" no quadro desta iniciativa, permitindo uma aproximação ao país real e autêntico. Neste sentido, os operários e o universo urbano são afastados da paisagem discursiva sobre Portugal, o que pode ser lido à luz da análise desenvolvida por Lebovics (1992) sobre o papel

9 RDP - Arquivo Histórico - AHD 5392, faixa 6, 13/03/1975.

10 Movimento, n. ${ }^{\circ}$ 4, 12/11/1974, p. 3.

l1 Partilho com Eric Wolf as características gerais que concorrem para a definição do camponês enquanto categoria conceptual: "Farm and household tend to coincide; production and consumption are closely integrated; the division of labour runs along lines of sex and age within the household" (2001b: 255). 
assimétrico que camponeses e operários desempenharam na guerra cultural em torno da imagem de França no final dos anos 30 do século XX.

No Programa de Dinamização Cultural, documento fundador desta iniciativa, o universo rural não é convocado de forma directa. A tónica é sobretudo colocada no país enquanto todo, sendo também referenciada a necessidade de intervenção em zonas específicas do território nacional. Assim, a indispensabilidade do trabalho da CODICE repousa na situação de "subdesenvolvimento cultural" do país "com maior incidência em certas zonas", ${ }^{12}$ esboçando-se já uma hierarquia dos lugares a percorrer. Esta duplicidade encontra-se igualmente presente nos discursos proferidos pelos principais responsáveis das Campanhas de Dinamização Cultural no seu acto inaugural. Ramiro Correia defende, por um lado, o objectivo de "ir a todos os lugares, levar as nossas vozes, levar as ferramentas que permitam interessar todos os portugueses na construção do país", sublinhado, por outro lado, que "a $10 \mathrm{~km}$ fora das cidades ninguém sabe o que se passou no país devido à situação de indigência política em que nos encontrávamos". ${ }^{13}$ Também Vasco Pinto Leite, na época Director-Geral da Cultura Popular e Espectáculos, ao mesmo tempo que enfaticamente afirma "que só há uma cultura", remetendo para o povo na sua feição englobante, refere que se constituirão "centros culturais na Província"14 no quadro do projecto de descentralização cultural, elemento mobilizador da adesão do sector intelectual às Campanhas de Dinamização Cultural e Acção Cívica.

Ultrapassada esta fase inicial, onde a tónica ora é colocada no país enquanto todo, ora na necessidade de intervenção em zonas específicas do território, os documentos posteriores da CODICE parecem evidenciar um consenso relativamente à opção pelo "Portugal dos campos" como destino privilegiado da sua acção, surgindo o "povo" como sinónimo de cultura camponesa.

Aquando da reorganização desta estrutura, apresentada nas páginas do boletim Movimento, em Maio de 1975, a centralidade deste universo é reforçada. O documento "Acção Cívica: passar das palavras aos actos", que fundamenta esta reestruturação e inaugura a "Acção Cívica", finaliza com um apelo à mobilização nacional, surgindo agora um claro reconhecimento que "o país do MFA" era o Portugal rural, com a definição da palavra de ordem "rumo ao campo", ${ }^{15}$

12 Estado-Maior das Forças Armadas, 5. ${ }^{a}$ Divisão, Programa de Dinamização Cultural, Comissão Dinamizadora Central, s/d [1974]. p. 1. Arquivo Histórico do Ministério da Defesa Nacional (em organização); caixa 6388 .

13 RDP - Arquivo Histórico, AHD 5847 - faixa 5, 25/10/1974.

14 Direcção-Geral da Cultura Popular e Espectáculos, Programa de Dinamização Cultural, s/d [1974], Centro Documentação 25 de Abril. Fundo Aida Ferreira. Caixa "CIASC Central VI, Pasta Documentação Recolhida Dinamização Cultural, Comissão Dinamizadora Central”.

15 Em diferentes momentos, o boletim Movimento reforçou a relevância da intervenção em contexto rural nos artigos que publicou sobre as diferentes campanhas. Por exemplo, no seu número 24, ao definir os objectivos da "Maio-Nordeste" é referida uma "ampla mobilização para os campos". Movimento, n. ${ }^{\circ} 24,25 / 7 / 1975$, p. 4. 
reforçando a ideia inicial do texto onde se fazia a apologia da "caminhada até às aldeias":

Num país que caminha para o Socialismo a atitude do povo terá que reflectir uma opção. Não poderemos prolongar o conformismo de fazer uma Revolução beneficiando dos confortos do capitalismo. Por outras palavras, torna-se necessário que os nossos técnicos, o nosso pessoal qualificado se regionalize, abandonando os centros urbanos e inicie a caminhada até às aldeias.

[...] Devemos rapidamente abalar estruturas baseadas em visões distorcidas, herdadas dum passado próximo e avançar, através de uma grande mobilização nacional, com a palavra de ordem, rumo ao campo. ${ }^{16}$

Também, no desenvolvimento das propostas delineadas na 2.. ${ }^{a}$ Directiva da CODICE que, reflectindo o Documento Guia da Aliança Povo-MFA, ${ }^{17}$ procurava fomentar os órgãos de "poder popular", o universo rural é novamente considerado através da invocação da "aldeia":

1. Os órgãos de base do poder popular no campo são os conselhos de aldeia. [...] uma das tarefas da Dinamização Cultural no Norte do País é a partir dos embriões de trabalho colectivo das populações incentivar e criar as condições para a organização ao nível de toda a aldeia ou lugar $[\ldots] .{ }^{18}$

Por fim, na Proposta de Aç̧ão Político-Militar, o último documento emanado da CODICE, a grande linha de força reside em "ganhar o campesinato pobre [...] para a revolução" através da "ocupação politica-militar do distrito da Guarda"19 que, com ligeiras alterações poderá ser aplicada a Bragança e Viseu” (Correia et al. s/d: 229-230). A escolha destes distritos é justificada por aí terem sido realizadas as últimas campanhas, e desta forma garantir um apoio continuado às populações, mas também por uma "urgência" que decorria do ciclo anual de produção, nomeadamente com o aproximar das colheitas da batata, cereais e do período das vindimas, e posterior necessidade de escoamento dos produtos.

Importa sublinhar que os protagonistas entrevistados no quadro desta investigação, quando se referiam ao país e à possibilidade de transformação que as Campanhas de Dinamização Cultural e Acção Cívica do MFA proporcionaram, invocam de forma directa o universo rural, por considerarem que o Portugal da "província" ou das "aldeias" se encontrava mais afastado do

16 Movimento, n. ${ }^{\circ} 18,20 / 5 / 1975$, p. 6.

17 Este documento foi aprovado em Julho de 1975 na Assembleia do MFA e procurava estabelecer formas de democracia directa, instaurando um projecto de poder popular.

18 Movimento, n. ${ }^{\circ}$ 25, 14/8/1975, p. 7.

19 Itálico no original. 
projecto revolucionário. Estes foram os terrenos eleitos de actuação, a partir dos quais se elaboraram imagens sobre o mundo rural, em concreto sobre as zonas de agricultura familiar do Norte do país. Neste sentido, o debate em torno dos terrenos a "dinamizar" acabaria também por repousar na dicotomia Norte-Sul, ${ }^{20}$ tão profusamente utilizada nos discursos pós-revolucionários (ver Brettel 1979). Apesar da realização de uma campanha de pequena dimensão em três concelhos do Algarve, a Sul a intervenção da CODICE não foi considerada prioritária, caracterizando-se sobretudo pela realização de sessões de esclarecimento e "gestão de conflitos" no quadro do movimento de ocupação de terras.

As diferenças entre o Norte e o $\mathrm{Sul}^{21}$ são convocadas na alusão à capacidade mobilizadora dos portugueses em torno do projecto revolucionário, isto é, servem para tematizar o "potencial revolucionário" (Brettell, 1979) destas duas grandes regiões do país. O Sul parece, assim, obedecer a uma linha retórica enaltecedora da dimensão política do povo, ancorada na retórica marxista da luta de classes, sendo justificada pelos protagonistas desta iniciativa pelo facto de a "população [se encontrar] mais próxima do 25 de Abril, mais politizada" (cassete n. ${ }^{\circ} 2$, 1999). No caso do Norte, este surge como "não revolucionário", constituindo um locus a partir do qual se criticam os múltiplos atrasos do país e, por conseguinte, se justifica a indispensabilidade da intervenção da CODICE.

Na verdade, a divisão ideológica entre o Norte e o Sul de Portugal ancora-se nos contrastes substantivos entre estas duas regióes, onde o regime de propriedade e a consciência de classe assumem uma importância de destaque. A estas diferenças da estrutura fundiária, geradoras de contrastes económicos e movimentos sociais distintos, Brettell (1979) associará o papel da emigração na problematização das razões que estariam na base desta representação antagónica de Portugal. Enquanto que no Sul os assalariados rurais viriam a integrar o proletariado urbano português com as migrações para o litoral, os camponeses integrariam o proletariado de países estrangeiros, onde a sua politização

20 Este movimento de apropriação bipartida do país circulou nos diferentes sectores da sociedade portuguesa, encontrando-se igualmente presente no cinema documental produzido na década de 70 (Leal et al 1993), onde se chamam duas zonas de Portugal com pressupostos e resultados distintos: Trás-os-Montes e Alentejo. Também a antropologia portuguesa denotou uma "preferência" pelo Norte camponês enquanto terreno de investigação, no qual o conceito de comunidade assumiu uma eficaz funcionalidade (Godinho 2002), em detrimento do Sul, exceptuando-se aqui o trabalho de Cutileiro (1977 [1971]), Vale de Almeida (1995) e, mais recentemente, Godinho (2001) e Fernandes (2006). Sobre as análises do Sul de Portugal tomando o Mediterrâneo como "conceito de referência", ver Leal (2001), onde o autor apresenta uma reflexão em torno dos trabalhos de Jorge Dias, Orlando Ribeiro e José Cutileiro.

21 Importa sublinhar que os resultados das eleições para a Assembleia Constituinte reforçaram esta imagem bipartida do país, uma vez que no Norte se concentrou a grande base de apoio social-democrata, ao passo que o Centro e o Sul votou maioritariamente no PS e PCP (André e Gaspar 1989). 
seria escassa. A emigração, ao afastar os indivíduos dos proletariados nacionais e estrangeiros, debilitaria a sua "experiência de classe" (Thompson 1989), tal como o minifúndio e a posse de terra.

Diferentes autores, como Hobsbawm (1989 [1983]), Herzfeld (1986), Wolf (200 la e b), Verdery (1991) e, mais recentemente, Hardt e Negri (2005), têm assinalado o desconforto que os camponeses têm colocado aos diferentes projectos de mudança política e social em diferentes contextos históricos. Para o modelo marxista que, nas suas diferentes "versões" foi hegemónico no período em análise, os camponeses encontravam-se claramente definidos como "não revolucionários" e "conservadores", tal como são descritos no Manifesto Comunista (Marx e Engels cit. em Wolf 200lb). Do ponto de vista político, como assinala Vigreux (2004), no século XIX o termo camponês assume uma conotação pejorativa. Contudo, dotou-se de um sentido inverso na viragem do século, nomeadamente a partir de 1903, quando as teses bolcheviques reconheceram ao mundo rural, operários agrícolas e pequenos camponeses, uma aptidão revolucionária (2004: 45 l).

Refira-se ainda que, no quadro das Campanhas de Dinamização Cultural e Acção Cívica do MFA, o camponês, utilizado pelo Estado Novo para veicular e fazer circular uma imagem pacífica e harmoniosa da nação, ${ }^{22}$ parecia ameaçar o projecto político do MFA. O que fazer para integrá-lo na reconstrução do país?

As Campanhas de Dinamização Cultural e Acção Cívica do MFA parecem responder a esta questão, uma vez que surgem, também, com o objectivo de despertar os camponeses para a sua vocação revolucionária que, estaria latente mas precisava de ser despertada, tornando-os cúmplices na construção do país, porque era necessário:

pôr em contacto tudo aquilo que está diferenciado, tudo aquilo que está em planos diferentes. Só quando o povo falar todo a mesma língua - a mesma língua que vise determinados objectivos que são a felicidade do povo português - uma maior justiça, uma maior evolução social, enfim uma maior

22 A antropologia portuguesa coadjuvou a construção desta imagem harmoniosa do mundo rural, nomeadamente com os trabalhos de Jorge Dias, Vilarinho da Furna, uma Aldeia Comunitária (1981) e Rio de Onor, Comunitarismo Agro-Pastoril (1981), onde a conflitualidade era episodicamente notada, imagem esta tão cara ao Estado Novo. Com a publicação dos trabalhos de Cutileiro (1977 [1971]), O'Neill (1984), Pina-Cabral (1986) e Brito (1996) opera-se uma ruptura teórica relativamente às propostas de Jorge Dias, desarmando a" ideologia" da igualdade.

Também Riegelhaupt (1981: 137), na esteira das propostas de James Scott e de Eric Wolf, chama a atenção para o facto de a historiografia portuguesa insistir na "visão elitista" de que a passividade era a "predilecção 'natural' dos camponeses". Contudo, como demonstraram Freire, Fonseca e Godinho (1999), os camponeses desenvolveram continuadas formas de resistência e de agitação durante o Estado Novo. 
igualdade económica, só quando assim for, é que estará completo o trabalho. $[\ldots]$

Porque o que nós visamos, o ideal que hoje queremos alimentar e cimentar, é precisamente o de fazer encontrar-se um povo que caminha para o futuro a passos cada vez mais gigantescos. É isso a Dinamização Cultural. (Correia et al. s/d: 76).

As campanhas cumpririam assim uma função homogeneizadora, procurando transformar os "camponeses em cidadãos" portugueses, tomando aqui de empréstimo o título da obra do historiador norte-americano Eugen Weber ${ }^{23}$ (1983 [1976]). O MFA procurou esclarecê-lo, apelando ao voto nas eleições para a Assembleia Constituinte, que se viriam a realizar a 25 de Abril de 1975. Referindo-se aos objectivos desta iniciativa, Geraldo Lourenço, praça da Armada, defende que o objectivo da dinamização cultural consistia em:

Levar a todo o país o espírito democrático da Revolução de Abril. [...] Nós íamos procurar dar às pessoas a capacidade de elas próprias, reconhecerem as suas dificuldades, elegerem os seus homens e as suas mulheres. [...] Nós dizíamos: não vimos aqui dar-vos nada, não temos nada para vos dar. Viemos trazer a liberdade e vocês vão-nos dar as vossas amarras. Vocês a partir de agora são livres. (Cassete n. ${ }^{\circ}$ 28, 2002)

4.

Orientadas para os objectivos que passei em revista, as Campanhas de Dinamização Cultural e Acção Cívica do MFA, ao elegerem a "ruralidade a norte" como centro mobilizador de práticas e discursos, irão fundar uma imagem paradoxal do "povo", agora "ressemantizado" e "reinventado" à luz de uma mundividência "revolucionária". Nesta paisagem discursiva irão dialogar imagens "monumentalizadoras" e "desmonumentalizadoras" (Leal e Branco, 1995) sobre o mundo rural, que ora se confrontam, ora se complementam, num processo de carácter polissémico, com intensidades diferentes de acordo com quem as constrói, que analisarei de seguida.

De facto, ao longo do seu período de vigência, a CODICE procedeu à construção de uma retórica assente num processo de circunscrição dos seus adversários - entenda-se o fascismo e os "elementos beneficiados pelo regime anterior" 24 - "desmonumentalizando" o Portugal dos campos que surge como um lugar de

23 A obra original intitula-se Peasants into Frenchmen. Contudo a edição de que disponho é a francesa, sendo esta que constará na bibliografia.

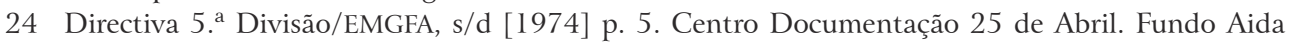
Ferreira. Caixa “CIASC Central VI, Pasta Documentação Recolhida Dinamização Cultural, Comissão Dinamizadora Central”. 
atraso ${ }^{25}$ económico, social e cultural, próximo do género contra-pastoral definido por Williams (1990 [1973]: 27-55). Este refúgio metafórico, no qual a ruralidade se encontra associada a um universo de sentidos fortemente negativo, é recorrente quer nos textos da época, ${ }^{26}$ quer nos discursos produzidos na actualidade pelos protagonistas da Dinamização Cultural e Acção Cívica.

Num balanço sobre a campanha realizada no Minho, publicado no boletim Movimento, podemos ler:

Saídos da noite fascista, a maioria dos portugueses desta zona vivem num ambiente crepuscular, em que o sol da verdadeira e plena liberdade só agora começa a surgir, por detrás das nuvens sombrias do obscurantismo cultural e político, do subdesenvolvimento, do depauperamento económico, na recusa da participação colectiva no trabalho revolucionário, quer por sujeição económica ou política, quer por desconhecimento da sua força. ${ }^{27}$

Importa sublinhar que o discurso legitimador das Campanhas de Dinamização Cultural e Acção Cívica do MFA assentava na constante denúncia das realidades encontradas tornando-as visíveis, próximo do olhar de Luís Buñuel em Las Hurdes (1933). Este documentário é inclusivamente convocado por um dos responsáveis da CODICE ao descrever as aldeias de uma freguesia da Beira Alta:

A habitação, de granito ou xisto e com cobertura de lousa é, na maioria dos casos desconfortável. [...] A nenhuma aldeia da freguesia de Covas do Rio se pode chegar de outra forma que não a pé. [...] As ruas, sem pavimento, atapetadas de urze putrefacta, os mostos transportados às costas por veredas e desfiladeiros, escolas em ruínas, habitações em que homens e animais têm abrigo comum,

25 Lains (2003) chama a atenção para a centralidade da ideia de "atraso económico" na historiografia portuguesa, cujas razões históricas remontam ao século XVIII, por altura da restauração e preservação da independência. $\mathrm{O}$ autor referencia a vertente política da retórica do atraso económico, aludindo a Antero de Quental e Oliveira Martins afirmando, também, que esta surge como "arma de arremesso na crítica da política contemporânea” (2003: 18) em diversas análises sobre ditadura militar (1926-1933) e sobre o Estado Novo.

26 Esta versão da ruralidade é particularmente manifesta até ao 11 de Março de 1975, momento a partir do qual a tónica é colocada no anticapitalismo, face à opção pelo modelo socialista. Como viria a afirmar o então primeiro-ministro Vasco Gonçalves referindo-se às cisões no seio do MFA:

"Na fase da luta anti-fascista directa, actuou-se com coerência e unidade, e o próprio processo se encarregou de isolar e eliminar os que o contrariavam. As dificuldades agudizaram quando a questão principal passou da destruição do fascismo para a construção do socialismo". (Chefe do Estado-Maior da Armada; Centro de Dinamização e Esclarecimento da Armada, 1975, "Aliança Povo/MFA. Documento de Análise Política apresentado na AMFA 8/9 de Julho de 1975 pelo Primeiro-Ministro Vasco Gonçalves e Aprovado na Generalidade”, p. 2. Arquivo particular de Manuel Madeira).

27 Movimento, n. ${ }^{\circ}$ 1 1, 25/2/1975, p. 3. Itálico meu. 
recordam ao visitante citadino, o documentário de Buñuel sobre as Hurdes. $^{28}$ (Correia et al. s/d: 112-113)

Referindo-se às mesmas aldeias, o então responsável pelo Gabinete Técnico da Agricultura da CODICE descreve-as da seguinte forma:

Era a miséria na sua forma mais desumana. Um domínio psicológico, total da igreja, havia uma subjugação física e psicológica das pessoas, falta de infra-estruturas a todo o nível, a falta de electricidade, a falta de caminhos, a falta de água, a água não tratada, o analfabetismo, esta conjugação, era de facto algo atroz. [...] De facto este país tinha situações gritantes, ainda as tem é certo, aldeias onde só de helicóptero é que se conseguia lá ir, na zona da serra da Freita e da Gralheira. Eram as terras onde a cabra mata o lobo e os mortos matam os vivos. O que é que isto quer dizer? [O relevo] era tão alcantilado, que eles, quando alguém morria tinha que ser levado às costas, e um dia o caixão caiu em cima de um e matou-o. E a cabra, naquele alcantilado, o lobo não conseguia apanhar a cabra. Isto dá uma ideia dos extremos que ali se viviam. (Cassete n. ${ }^{\circ}$ 14, 2000)

Sublinhando a versão cultural do atraso, um dos colaboradores do sector do teatro ao referir-se ao projecto de descentralização afirma:

A ideia de base era descentralizar, entendendo a descentralização como a confrontação como novos públicos, e com públicos que raramente tinham o acesso físico e real com este tipo de arte e espectáculos. [...]

Do ponto de vista da instrução a maioria tinha a $4 .^{\text {a }}$ classe, se tivesse. Do ponto de vista da cultura era muito reduzida, entendendo por cultura, um conjunto de vivências e informações; como informação era reduzida, portanto a cultura era necessariamente reduzida, neste sentido, cultura-instrução. (Cassete n. ${ }^{\circ}$ 15, 2000)

O povo rural é visto como vítima de um Estado fascista que o concebia como "objecto de folclore" ao qual restava "saber ler e escrever, para ser feliz". ${ }^{29}$ Esta crítica ao movimento folclorista do Estado Novo tem eco nos discursos actuais dos protagonistas da Dinamização Cultural, onde o seu posicionamento face à concepção de folclore e cultura popular do Estado Novo funda um campo

28 Itálico meu. Esta descrição de Ramiro Correia aproxima-se da visão da ruralidade subjacente ao Inquérito à Habitação Rural organizado pelo Instituto Superior de Agronomia, cujos resultados viriam a ser publicados nos anos 40 do século XX. Sobre este assunto ver análise de Leal (2000).

29 Movimento, 12/11/1974, p. 1. 
discursivo fortemente negativo. Neste sentido, Modesto Navarro, coordenador da área literária da CODICE, afirma:

A destruição da cultura popular, foi feita muito antes, condicionada e direccionada, para as vias que lhes interessava. O teatro popular, de denúncia, de crítica social, etc., foi destruído e é irrecuperável, aquilo que eram tradições das aldeias. [...] As vestes não correspondiam nada à etnografia e às tradições locais e eles imprimiam os seus ritmos, as suas visões de bonitinho, de pitoresco, esvaziando de sentido aquilo que entroncava e enraizava na vida das pessoas. (Cassete n. ${ }^{\circ}$ 5, 2000)

Desta forma, folclore e cultura popular surgem como o resultado de um processo de "abastardamento" 30 da cultura pelo fascismo, o que contribuiu para reforçar uma imagem negativizada do povo.

Esta narração negativa de nação, que se organiza em torno do nexo camponeses-fascismo, rivaliza paradoxalmente com outra imagem que faz o elogio da ruralidade num tom de valorização das culturas locais, concebidas já não como "tradições esvaziadas de sentido" mas como a "expressão autêntica dum povo" ${ }^{31}$ No I Congresso dos Escritores Portugueses realizado em Maio de 1975, o então primeiro-ministro Vasco Gonçalves, no seu apelo à participação dos intelectuais portugueses na construção do Portugal democrático e socialista, salienta:

Essa cultura tem que ser elaborada com o povo. Mas não com um ar paternalista. Tem de se mergulhar nas raízes da vida popular. Eu cito aqui em toda a humildade, o que nós militares, temos aprendido nas campanhas de dinamização popular. (Gonçalves 1976: 209)

Apesar de na época este enaltecimento ser partilhado por militares e civis, actualmente é expresso de forma mais enfática pelo sector intelectual e por técnicos civis que intervieram em outras áreas consideradas pela CODICE. Como sublinhou Verdery (1991: 89), todos os novos regimes e novas ordens políticas tentam captar os intelectuais e os seus "talentos" na legitimação da sua liderança, e o MFA, através das suas Campanhas de Dinamização, não foi excepção.

O engagement dos intelectuais no projecto de descentralização cultural pautava-se pelo apoio às diferentes regiões do país na edificação de "centros

30 Palavras de Mário Dionísio cit. em Correia et al. (s/d: 17)

31 Direç̧ão-Geral da Cultura Popular e Espectáculos, Programa de Dinamização Cultural, s/d [1974], Centro Documentação 25 de Abril. Fundo Aida Ferreira. Caixa "CIASC Central VI, pasta Documentação Recolhida Dinamização Cultural, Comissão Dinamizadora Central”. 
culturais" e na partilha do seu trabalho com outros "públicos". Porém, o contacto com a realidade que a revolução desvelou potenciou um discurso enaltecedor das culturas locais, no sentido de recuperar as "tradições" que durante 48 anos foram manipuladas pelo regime deposto. Estas eram concebidas como um património passível de ser partilhado e utilizado como experiência formadora. Neste sentido, atente-se ao relato de uma colaboradora da CODICE, ao referir-se ao seu trabalho em Castro Daire (distrito de Viseu) na área da educação:

O país tinha um sistema social que tinha sido decretado por uma revolução. Com este facto, as pessoas podiam fazer imensas coisas, entre elas a valorização. O slogan "o Povo está com o MFA", no fundo, é o reconhecimento, aliás e eu explicava isto, de que o MFA tinha valorizado o povo português.

O nosso papel foi dinamizar esse potencial humano que, de facto, foi ostracizado por um sistema social que impedia que as pessoas fossem valorizadas. Portugal era o folclore, era aquela dimensão de bilhete-postal para o urbano ver.

Ao nível da equipa, e estou a falar da CODICE, estou a falar de um conceito de povo, de povo que sabe, que tem uma história, que tem um conhecimento profundo, que é o conceito do conhecimento dos artefactos de sobrevivência, desde o trabalho, quer dizer, as soluções que as pessoas encontram no mundo rural é de uma sabedoria imensa, estou a falar de um conhecimento técnico. E habitualmente há um conceito de povo que é de ignorante, de iletrado [...]. O conceito de povo era um conceito de valor, de competência, grupos humanos com uma competência enorme, quer ao nível técnico, social e cultural. (Cassete n. ${ }^{\circ}$ 9, 2000)

Já Carlos Paulo, actor do grupo de teatro Comuna, refere como a forma de organização comunitária, característica do Norte do país, os influenciou na adaptação da obra Era uma Vez do dramaturgo brasileiro Alfredo Nery Paiva, que fizeram especificamente para as campanhas (cassete n. ${ }^{\circ} 42,2004$ ).

Em convergência com esta imagem positiva do povo, e enquadradas por aquilo que Ridenti designou de "utopia da integração do intelectual com o povo" (2000: 12), encontram-se as palavras de um técnico da Direcção-Geral dos Desportos que participou nas campanhas da Guarda e Trás-os-Montes. O trabalho com as populações e associações locais na construção de ginásios rurais foi descrito como:

uma experiência muito interessante. Éramos jovens, acreditávamos na transformação [...] e para muitos jovens quadros foi uma espécie de descobrir o que estava para conhecer, sobretudo para mim que era um urbano 
[...]. Por exemplo, tive a oportunidade de juntar um conjunto de slides sobre jogos tradicionais $[\ldots]$. Eu vi jogos, lengalengas, que nunca tinha ouvido falar. (Cassete n. ${ }^{\circ}$ 22, 2002)

Esta sedução pelo mundo rural terá de ser colocada num quadro comparativo mais vasto, uma vez que atravessa os vários períodos da história portuguesa (ver Leal 2000; Melo 200 1; Castelo-Branco e Branco 2003, entre outros) e europeia (Thompson 1998; Thiesse 2000; Bendix 1997; Burke 1998), reflectindo-se na própria história da antropologia (ver Kearney 1996) e na forma como construiu o seu objecto de estudo.

Contudo, a singularidade do contexto sociopolítico que enquadra esta paisagem discursiva reenvia-nos para o conceito de "romantismo revolucionário", proposto por Ridenti (2000) ao trabalhar o movimento cultural e político do Brasil dos anos 60, princípio de 70. A utopia revolucionária romântica valorizava, acima de tudo, a vontade de transformação e o papel dos seres humanos para mudar a história. Contudo, o arquétipo dos novos sujeitos históricos tinha, também, como filão a cultura popular de matriz rural, cuja autenticidade fora perdida ou ocultada pela acção do Estado Novo, procurando-se resgatar a sua pureza, desfascizando-a.

5.

A etnografia aqui apresentada permite aceder a um campo discursivo sobre Portugal no período da transição democrática, onde o povo enquanto sinónimo de ruralidade foi convocado como aliado do processo revolucionário.

Este movimento, perspectivado como um processo de integração do camponês num novo projecto político, procurou pôr em diálogo diferentes versões da ruralidade, unificadas por um pólo, agora legitimado, a partir do qual é pensado o país: a cultura socialista.

O período em análise surge como um momento de ruptura com o Estado Novo e com uma concepção do país enquanto um todo harmónico, pictórico, folclórico, onde as rupturas e as contradições eram ocultadas. Contudo o MFA, ao eleger os camponeses como categoria da população representativa do povo português, no quadro das suas Campanhas de Dinamização Cultural e Acção Cívica, entra em linha de continuidade com o regime que lhe antecedeu, uma vez que a equação "povo-ruralidade" persiste com outros contornos.

No trilho de Marx, ao qual se aliaria Antonio Gramsci, o novo, por mais revolucionário que possa ser na realidade, é sempre uma resposta ao passado (Crehan 2004: 37), e a inteligibilidade da mudança reside na dialéctica passado-presente. No quadro desta iniciativa o tempo pretérito é conceptualizado numa dupla perspectiva. Por um lado, evoca-se um passado opressor, marcado 
por recuos e insucessos, tomado agora como elemento de ruptura no processo de "reconstrução do país". Por outro, o encontro com um passado velado, agora redescoberto, é enfatizado na apologia do país autêntico e verdadeiro.

Apesar da característica fracturante das construções discursivas daqueles que protagonizaram esta iniciativa, legível na forma como tematizaram o país através dos novos conceitos utilizados e do recurso a diferentes mecanismos retóricos, estas exprimiram-se também, com um stock de imagens e concepções já existentes, ${ }^{32}$ conferindo-lhes outro sentido procurando, desta forma, garantir a sua eficácia.

\section{BIBLIOGRAFIA}

ALMEIDA, Miguel Vale de, 1995, Senhores de Si: uma Interpretação Antropologica da Masculinidade. Lisboa, Fim de Século.

ANDERSON, Benedict, 1991 [1983], Imagined Communities. Reflections on the Origin and Spread of Nationalism. Nova Iorque, Verso.

ANDRÉ, Isabel; e Jorge Gaspar, 1989, "Portugal - geografia eleitoral: 1975 e 1987" em Mário Baptista Coelho (ed.), O Sistema Político e Constitucional (1975-1977). Lisboa, Imprensa de Ciências Sociais, 257-277.

BENDIX, Regina, 1997, In Search of Authenticity: The Formation of Folklore Studies, EUA. The University of Wisconsin Press.

BOURDIEU, Pierre, 1996 [1984], "Los usos del 'pueblo"', Cosas Dichas. Barcelona, Gedisa Editorial, 152-157.

—, 1998 [1982], O Que Falar Quer Dizer, A Economia das Trocas Linguísticas. Lisboa, Difel.

BRETTELL, Caroline B., 1979, "Emigration and its implications for the revolution in northern Portugal” em S. Lawrence Graham e Harry M. Makler (eds.), Contemporary Portugal: The Revolution and Its Antecedents. University of Texas Press, Austin, 281-298.

BRITO, Joaquim Pais de, 1995, "No tempo da descoberta de um escultor", Onde Mora o Franklin, um Escultor do Acaso. Lisboa, MNE, 11-22.

—, 1996, Retrato de uma Aldeia com Espelho, Ensaio sobre Rio de Onor. Lisboa, Publicações D. Quixote.

BURKE, Peter, 1998, Cultura Popular na Idade Moderna - Europa, 1500-1800. São Paulo, Companhia das Letras.

32 Como afirmam Castelo-Branco e Branco (2003: 15) para o caso do folclore, a passagem do autoritarismo para a democracia não significou uma ruptura ao nível dos conteúdos, verificando-se uma continuidade. A bibliografia em torno da dicotomia continuidade vs ruptura nas mudanças de regime é assinalável (ver Faure 1989; Lebovics 1992; e Peer 1998). Para o caso português, Leal (2000: 47) sublinha a continuidade entre a I República e Estado Novo ao nível da etnografia e da concepção de cultura popular. 
CANCLINI, Néstor Garcia, 1997, Culturas Híbridas, Estratégias para Entrar e Sair da Modernidade. São Paulo, Editora da Universidade de São Paulo.

CASTElO-BRANCO, Salwa El-Shawan, e Jorge Freitas Branco (eds.), 2003, Vozes do Povo: a Folclorização em Portugal. Oeiras, Celta.

CORreiA, Ramiro, et al. s/d, MFA, Dinamização Cultural, Acção Cívica. Lisboa, Ulmeiro.

CREHAN, Kate, 2004, Gramsci, Cultura e Antropologia. Lisboa, Campo da Comunicação.

CRUZEIro, Maria Manuela, 1994, "O imaginário político do 25 de Abril”, Revista de História das Ideias, vol. 16, Instituto de História e Teoria Ideias Faculdade de Letras, Coimbra, 433-476.

CUTILEIrO, José, 1977 [1971], Ricos e Pobres no Alentejo. Lisboa, Livraria Sá da Costa.

DIAS, Jorge, 1981 [1948], Vilarinho da Furna, uma Aldeia Comunitária. Lisboa, INCM.

__, 1981 [1953], Rio de Onor, Comunitarismo Agro-Pastoril. Lisboa, Presença.

ELSTER, Jon, 1998, "Coming to terms with the past. A framework for the study of justice in the transition to democracy", Archives Européennes de Sociologie, Tomo XXXIX, n. ${ }^{\circ}$ 1, 7-48.

FAURE, Christian, 1989, Le Projet Culturel de Vichy, Folklore et Révolution Nationale 1940-1944. Lyon, Presses Universitaires de Lyon.

FERNANDES, Margarida, 2006, Terra de Catarina, Do Latifundio à Reforma Agrária, Ocupação de Terras e Relações Sociais em Baleizão. Oeiras, Celta Editora.

FOUCAUlT, Michel, 1998, As Palavras e as Coisas. Lisboa, Edições 70.

FREIRE, Dulce; Inês Fonseca, e Paula Godinho, 1999, Resistência e Agitação no Contexto Rural Português (1926-1974), relatório final de investigação. Fundação para a Ciência e Tecnologia, Lisboa, dactilografado.

GIL, José, 1995, Salazar: a Retórica da Invisibilidade. Lisboa, Relógio de Água.

GODInHO, Paula, 2001, Memórias da Resistência Rural no Sul. Couço (1958-1962). Oeiras, Celta Editora.

—, 2002, "Comunidade, classe e colectivos no Sul de Portugal (Couço, 1958-1962)", Ler História, n. ${ }^{\circ}$ 40, 127-139.

GONÇALVES, Vasco, 1976, Vasco Gonçalves, Discursos, Conferências de Imprensa, Entrevistas. Lisboa, A.P. da Gama

HANN, C. M. (ed.), 1994, When History Accelarates, Essays on Rapid Social Change and Creativity. Londres, The Athlone Press.

HARDT, Michael; e António Negri, 2005, Multidão, Guerra e Democracia na Era do Império. Porto, Campo das Letras.

HERZFELD, Michael, 1986, Ours Once More, Folklore, Ideology, and the Making of Modern Greece. Nova Iorque, Pella Publishing Company.

HOBSBAWM, Eric; e T. Ranger (eds.), 1989 [1983], The Invention of Tradition. Cambridge, Cambridge University Press.

HOBSBAWM, Eric, 1989 [1983], “Mass-producing traditions: Europe, 1870-1914” em Eric Hobsbawm; e Terencer Ranger (eds.), The Invention of Tradition. Grã-Bretanha, Cambridge University Press, 263-307.

JUlliard, Jacques, 1992, "Le peuple”, em Pierre Nora (ed.) Les Lieux de Mémoire, III France, 1. Conflits et Partages. Paris, Gallimard, 185-229.

KEARNEY, Michael, 1996, Reconceptualizing the Peasantry, Anthropology in Global Perspective. Colorado, Westview Press.

LAINS, Pedro, 2003, O Progresso do Atraso. Uma Nova História Económica de Portugal 1842 -1992. Lisboa, Imprensa de Ciências Sociais. 
LEAL, João, 2000, Etnografias Portuguesas (1870-1970), Cultura Popular e Identidade Nacional. Lisboa, Publicações D. Quixote.

—_, 2001, "Orlando Ribeiro, Jorge Dias e José Cutileiro: imagens do Portugal mediterrânico", Ler História, n. ${ }^{\circ}$ 40, 141-163.

LEAL, João, et al (eds.), 1993, Olhares sobre Portugal. Cinema e Antropologia. Lisboa, Centro de Estudos de Antropologia Social-ABC Cine Clube.

LEAL, João, e Jorge Freitas Branco, 1995, "Introdução", Revista Lusitana (nova série), n. ${ }^{\circ}$ 13-14, 1-12.

LEBOVICS, Herman, 1992, True France. The Wars Over Cultural Identity, 1900-1945. Ithaca, Cornell University Press.

Livro Branco da 5. ${ }^{a}$ Divisão, 1974-1975, 1984. Lisboa, Ler Editora.

LÖFGREN, Orvar, 1989, “The nationalization of culture”, Ethnologia Europaea, XIX, 5-24.

LOUREnÇO, Eduardo, 1988, O Labirinto da Saudade, Psicanálise Mítica do Destino Português.

Lisboa, Círculo de Leitores.

MARX, Karl, 1975 [1869], O 18 Brumário de Louis Bonaparte. Coimbra, Centelha.

MAUSS, Marcel, 1988 [1950], Ensaio sobre a Dádiva. Lisboa, Edições 70.

MELO, Daniel, 2001, Salazarismo e Cultura Popular (1933-1958). Lisboa, Imprensa de Ciências Sociais.

NEIBURG, Federico, 1997, Os Intelectuais e a Invenção do Peronismo. São Paulo, Editora da Universidade de São Paulo.

OLIVEN, Ruben George, 1992, A Parte e o Todo. A Diversidade Cultural no Brasil-Nação. Petrópolis, Vozes.

O’NEILl, Brian, 1984, Proprietários, Lavradores e Jornaleiras, Desigualdade Social numa Aldeia Transmontana (1870-1978). Lisboa, Publicações D. Quixote.

PAlaCiOS, Diego, 2003, O Poder Caiu na Rua. Crise de Estado e Acções Colectivas na Revolução Portuguesa. Lisboa, Imprensa de Ciências Sociais.

PEER, Shanny, 1998, France on Display. Peasants, Provincials and Folklore in 1937 Paris World Fair. Nova Iorque, State University of New York Press.

PÉREZ LEDESMA, Manuel, 1997, "Presentación” em Rafael Cruz, e Manuel Pérez Ledesma (eds.), Cultura y Movilización en la España Contemporânea. Madrid, Alianza Universidad, 9-12.

PINA-CABrAl, João de, 1986, Filhos de Adão, Filhas de Eva, A Visão do Mundo Camponesa no Alto Minho. Lisboa, Publicações. D. Quixote.

PINTO, António Costa, 2004, "Ajustando contas com o passado na transição para a democracia em Portugal", em Alexandra Barahona Brito, et al. (eds.), Política da Memória, Verdade ou Justiça na Transição para a Democracia. Lisboa, Imprensa de Ciências Sociais, 87-108.

PIRES, José Cardoso, 1975, "Prefácio" em João Abel Manta, João Abel Manta, Cartoons 1969-1975. Lisboa, Edições O Jornal, 5-7.

—, 1999, "Literatura e revolução dos cravos" em E Agora, José?. Lisboa, Publicações D. Quixote, 223-230.

RAPOSO, Paulo, 1998, “O Auto da Floripes: 'cultura popular', etnógrafos, intelectuais e artistas”, Etnográfica, vol. II (2), CEAS/Celta, Novembro, 189-219.

RIDENTI, Marcelo, 2000, Em Busca do Povo Brasileiro, Artistas da Revolução, do CPC à Era da $T V$. Rio de Janeiro, Record.

RIEGELHAUPT, Joyce F., 1981, "Camponeses e o estado liberal: a revolta da Maria da Fonte”, Estudos Contemporâneos, n. ${ }^{\circ}$ 2/3, Porto, 129-139 
SCOTT, James C., 1998, Seeing Like a State, How Certain Schemes to Improve the Human Condition Have Failed. New Haven, Londres, Yale University Press.

SILVA, Augusto Santos, 1994, Tempos Cruzados, Um Estudo Interpretativo da Cultura Popular. Porto, Edições Afrontamento.

SMITH, Anthony D., 1997 [1991], A Identidade Nacional. Lisboa, Gradiva.

THIESSE, Anne-Marie, 2000, A Criação das Identidades Nacionais. Lisboa, Temas e Debates. THOMPSON, E.P., 1989, La Formación de la Clase Obrera en Inglaterra, tomo 1. Barcelona,

Editorial Crítica.

— 1998, Costumes em Comum. São Paulo, Companhia das Letras.

TRINDADE, Luís, 2004, "Os excessos de Abril”, História, n. ${ }^{\circ}$ 65, Abril, 21 -31.

VERDERY, Katherine, 1991, National Ideology Under Socialism, Identity and Cultural Politics in Ceausescu's Romania. EUA, University of California Press.

VIGREUX, Jean, 2004 “Os camponeses comunistas” em Michel Dreyfus, Bruno Groppo,

Cláudio Ingerflom, Roland Lew, Claude Pennetier, Bernard Pudal, e Serge Wolikow (eds.), O Século dos Comunismos. Lisboa, Editorial Notícias, 45 1-466.

WEBER, Eugen, 1983 [1976], La Fin des Terroirs. La Modernisation de la France Rurale 1870-1914. Paris, Fayard.

WILliamS, Raymond, 1990 [1973], O Campo e a Cidade na História e na Literatura. São Paulo, Companhia das Letras.

WOLF, Eric, 2001 a, "Peasants and revolution", Pathways of Power, Building Anthropology in the

Modern World. EUA, University of California Press, 230-240.

— $200 \mathrm{lb}$, "Is the 'peasantry' a class", Pathways of Power, Building Anthropology in the Modern World. EUA, University of California Press, 252-259.

\section{OUTRAS FONTES}

\section{Publicações periódicas}

Diário Popular.

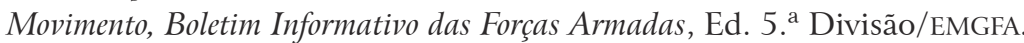

\section{Fontes arquivísticas}

Arquivo Histórico da Rádio Difusão Portuguesa (AHD 5847 - faixa 5, 25/10/1974; AHD 5392, faixa 6, 13/03/1975).

Arquivo Histórico do Ministério da Defesa Nacional (em organização) - Caixas 6355 e 6388. Centro de Documentação 25 de Abril - Universidade de Coimbra:

- Fundo Comunicados e Panfletos, caixa Forças Armadas-EME, pasta EME,

Gabinete de Dinamização do Exército, Diversos; Fundo Aida Ferreira.

- Caixa CIASC Central vi, pasta Documentação Recolhida Dinamização Cultural, Comissão Dinamizadora Central.

Arquivos particulares de Manuel Madeira e de Rodrigo de Freitas.

\section{Entrevistas gravadas}

Cassete n. ${ }^{\circ}$ 2, 1999; cassete n. ${ }^{\circ} 4$, 2000; cassete n. ${ }^{\circ}$ 5, 2000; cassete $n .^{\circ}$ 9, 2000; cassete n. ${ }^{\circ} 14,2000$; cassete n. ${ }^{\circ} 15,2000$; cassete n. ${ }^{\circ} 22$, 2002; cassete $n .^{\circ} 28,2002$; cassete n. ${ }^{\circ}$ 36, 2002; cassete n. ${ }^{\circ}$ 38, 2004; cassete n. ${ }^{\circ} 41,2004$; e cassete n. ${ }^{\circ} 42,2004$. 


\section{"The journey to the villages": Rurality in the transition to democracy in Portugal}

\section{Sónia Vespeira de Almeida}

Doutoranda em Antropologia (ISCTE). Investigadora do CEEP (Universidade Nova de Lisboa - FCSH). Bolseira FCT-FSE (III Quadro Comunitário de Apoio).

sonia.almeida@fcsh.unl.pt

This article examines the representations of rural Portugal in the light of Portuguese democratic transition, taking as an empirical field the Campanhas de Dinamização Cultural e Acção Cívica do Movimento das Forças Armadas (1974-1975). Trying to confront the "idea of Portugal" promoted by the Estado Novo the protagonists of this initiative construct a paradoxical discursive field, where concepts such as culture, tradition, underdevelopment, decentralization and citizenship are intertwined.

KEYWORDS: peasants, folk culture, revolution, Movimento das Forças Armadas. 